\title{
Pengenalan Playback Theater sebagai Metode Berteater untuk Melepaskan Ketegangan
}

\author{
Riyana Rizki Yuliatin ${ }^{1}$, Puspita Dewi ${ }^{2}$, Hary Murcahyanto ${ }^{3}$, Sandy Ramdhani ${ }^{4}$, Hilda Hastuti ${ }^{5}$ \\ riyanarizki.y@gmail.com ${ }^{1}$, puspitadewi@universitasbumigora.ac.id ${ }^{2}$, \\ harymurcahyanto@gmail.com ${ }^{3}$ sandy160392@gmail.com ${ }^{4}$, \\ hildahastuti@universitasbumigora.ac.id ${ }^{5}$ \\ 1,3,4 Universitas Hamzanwadi, ${ }^{2,5}$ Universitas Bumigora
}

\section{Article History:}

Received: 04-01-2021

Accepted: 28-01-2021

Keywords: playback theatre, tension release, theatre method

\begin{abstract}
Various ways used to express ideas, feeling, and opinions. Art is one of the most effective modes to convey the emotions. Playback theatre by combining artistic relation and social relation becomes a method applied. Playback theatre concerns on telling process. Pre-test and post-test were conducted to identify the previous knowledge of the participants before providing materials and to recognize the knowledge after the activity. The service community activity results show that playback theatre has a positive impact to the participants to reduce nervous and it establishes chemistry between actors and music players so that the performance could be satisfied and better. It is expected that other lecturers or researchers implement and develop the playback theatre method to decrease tension and nervous in playing roles as actors.
\end{abstract}

\section{Pendahuluan}

Kesenian menjadi satu metode untuk mengekspresikan diri. Menjadi guru seni, tidak hanya dituntut mampu mengajarkan suatu kesenian pada anak didik, tetapi juga mampu membantu peserta didik mengungkapkan ekspresi diri. Seni juga mampu membantu peserta didik dalam menyalurkan segala sesuatu yang tersimpan dalam dirinya. Wastap dalam penelitian menyebutkan bahwa teater menjadi media komunikasi pendidikan paling dasar atau awal hingga tinggi (Wastap, 2019). Sayangnya, tidak semua peserta didik mampu melakukannya dengan mudah. Padahal, remaja dengan sekelumit kehidupan sosialnya memiliki kerentanan dalam masalah psikologis. Berbagai peristiwa dalam hidup tidak jarang meninggalkan tekanan, mulai dari yang ringan hingga yang berat. Tidak sedikit dari segala kejadian yang dialami sehari-hari meninggalkan ketegangan. Ketegangan akibat peristiwa-persitiwa yang tidak menyenangkan tidak seharusnya disimpan berlamalama. Hal ini karena pengalaman traumatis dapat menggoncangkan dan melemahkan pertahanan individu dalam menghadapi tantangan sehari-hari (Hatta, 2016). Maka penting untuk menyingkirkan hal atau peristiwa yang tidak menyenangkan tersebut.

Bercerita menjadi cara yang paling sederhana yang bisa dilakukan untuk mengurangi ketegangan atau trauma. Dengan bercerita, kesedihan, ketakutan, dan 
kekhawatiran bisa diluapkan (Hasiana, 2019). Dengan mengeluarkan segala yang terpendam dalam dada atau pikiran dapat meringakan dan memberi kelegaan pada diri seseorang. Memendam sesuatu justru akan memperparah keadaan yang ada di dalam. Seperti suatu kerusakan, ia akan menjalar ke yang lainnya. Cerita-cerita yang berasal dari ketegangan atau trauma muncul dalam konteks yang berbeda. Dalam beberapa kasus, kita mungkin dapat menebaknya. Tetapi di lain pihak terkadang kita akan terkejut olehnya. Tidak jarang cerita-cerita yang lahir dari ketegangan atau trauma dapat menyentuh hati ketika mendengarkan. Hal ini dikarenakan cerita-cerita traumatis biasanya memberi kesan mendalam pada pendengarnya.

Playback theatre merupakan salah satu metode berkesenian yang biasa digunakan untuk mengurangi ketegangan. Playback theatre mengombinasikan ekspresi artistic dan hubungan sosial melalui metode bercerita dan menyimak dengan empatik yang bisa mengarah pada pemulihan seseorang (Moran \& Alon, 2011). Jenis teater ini juga dijadikan salah satu metode yang biasa diterapkan untuk membantu pemulihan pasca bencana atau peristiwa traumatis lainnya. Playback theatre berpusat pada proses bercerita atau transformasi peristiwa dari si pemilik cerita kepada aktor dan penonton. Playback theatre mencakup seluruh dimensi kepribadian pemilik cerita (kognisi, afeksi, perilaku, dan motivasi) yang terwujud dalam satu pementasan (Hadriami \& Samuel, 2016). Meski playback theatre membangun jarak emosi antara pencerita dengan aktor, tetapi Landy menyebutkan bahwa dalam playback theatre terjadi reduksi tegangan dan trauma melalui tubuh aktor (Rogers, 2005).

Inilah titik utama dari kegiatan pengabdian ini. Metode berteater ini masih tergolong asing di kalangan mahasiswa Pendidikan Seni Drama, Tari, dan Musik Universitas Hamzanwadi. Sebagai calon pendidik, penting bagi mereka untuk mengenalkan metode berteater ini sebagai alternatif berteater. Yuliatin dan Satrya HD menyebut telah banyak yang kajian pada teater yang bergerak ke depan dan belakang (Yuliatin \& Satrya, 2019). Penelitian ke depan mengarah pada teater modern dan postmodern, sedangkan ke belakang mengarah pada teater rakyat. Dengan banyaknya kedua arah kajian ini mahasiswa telah mengenal baik teater tradisi dan konvensional. Sementara playback theatre masih tergolong asing. Kegiatan ini dikemas dengan konsep workshop agar mahasiswa tidak hanya mendapat teori semata melainkan juga dapat merasakan pengalaman langsung dalam melakukan playback theatre. Harapannya dengan menyebarkan pengetahuan ini pada mahasiswa akan ada proses transfer ilmu yang panjang, sebab nantinya mahasiswa akan menjadi guru dan menyebarluaskan pengetahuan yang sama. 


\section{Metode}

Kegiatan dilakukan dalam bentuk pembinaan terhadap mahasiswa Pendidikan Seni Drama, Tari, dan Musik Universitas Hamzanwadi. Pembinaan berupa workshop, diskusi, hingga penggarapan atau praktek playback theatre. Workshop sendiri dilakukan selama sehari. Setelah itu akan dilakukan pembinaan untuk menyusun dan menyiapkan pertunjukan playback theatre. Selama menyusun atau mempersiapkan pertunjukan, pertemuan tetap dilakukan untuk memantau perkembangan mahasiswa. Pertemuan tersebut dilakukan sekali dalam seminggu. Alokasi waktu dalam setiap pertemuannya yaitu 90 menit. Kegiatan dilakukan pada hari Sabtu. Dimulai pukul 16.00 sampai dengan 17.30. Setiap kegiatan tetap dalam pemantauan. Jumlah peserta akan dimaksimalkan 20 orang. Hal ini untuk menjaga kualitas proses pembelajaran. Dengan harapan ke depannya 20 orang tersebut dapat membagi pengalamannya pada teman-teman yang lain. Pembinaan dilaksanakan di Panggung Putih Universitas Hamzanwadi.

\section{Pembahasan}

Materi dibuka dengan melakukan pretest. Pretest berupa pemberian stimulus beberapa pertanyaan yang berhubungan dengan playback theatre. Pretest menjadi alat ukur pengetahuan peserta tentang materi yang akan disampaikan. Peserta memberikan respons yang baik terhadap stimulus yang diberikan. Jawaban-jawaban yang diberikan peserta menunjukkan bahwa playback theatre masih tergolong asing. Akan tetapi, mereka bersedia untuk berposes dalam mengenal jenis teater tersebut.

Kegiatan ini dilakukan dalam tiga fase. Fase pertama dimulai dengan pemberian materi tentang playback theatre. Pada fase kedua dilakukan pembagian peran pada masingmasing peserta. Mulai dari conductor, pemain, pemain musik. Fase ketiga mulai dilakukan praktek pementasan playback theatre.

Fase pertama dimulai dengan memperkenalkan playback theatre. Playback theatre masih menjadi barang baru bagi para peserta. Untuk membantu mempermudah pemahaman peserta, mula-mula peserta diberikan waktu untuk menonton pertunjukan playback theatre. Hal ini dilakukan agar saat pemberian materi peserta tidak dalam keadaan kosong. Mereka telah memiliki gambaran tentang jenis teater tersebut.

Setelah menonton pertunjukan playback theatre, peserta ditanya pertanyaan yang berkaitan dengan materi, antara lain:

1. Apa yang membedakan pertunjukan teater konvensional dan playback theatre?

2. Apa yang paling utama terlihat dari pertunjukan playback theatre?

3. Simpulkan secara singkat tentang playback theatre!

4. Bagaimana playback theatre dimainkan? 


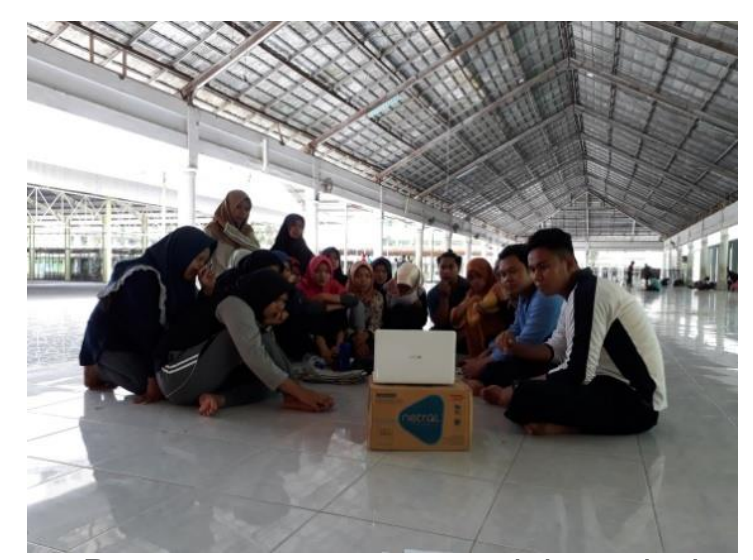

Gambar 1. Peserta menonton pertunjukan playback theatre

Dari keempat pertanyaan tersebut, para peserta mampu menjawab pertanyaan pertama dan kedua. Sedangkan dua pertanyaan lain tidak bisa dijawab. Kondisi sangat wajar dengan melihat keadaan peserta masih sangat asing ketika berhadapan dengan playback theatre. Setelah mendapat pemahamanan singkat dari video pertunjukan, kegiatan dilanjutkan dengan pemberian pemahaman mendalam tentang playback theatre. Pada pelaksanaannya, pemberian materi utuh dirasakan lebih mudah setelah peserta menonton video pertunjukan. Peserta memiliki referensi dasar saat diberikan materi. Jadi peserta tidak mengawang-awang atau menerka-nerka setiap konsep baru. Playback theatre tergolong memiliki bentuk pertunjukan yang berbeda. Fox menyebutkan bahwa playback theatre adalah metode berteater yang humble (Fox, 2007) sebab aktor dan pemain musik memainkan peran berdasarkan cerita hidup dari pencerita atau audiens, tanpa panggung layaknya pertunjukan konvensional, tanpa kostum dan naskah.

Penyampaian materi dilakukan dalam urutan, yaitu definisi, sejarah, dan diakhiri dengan metode melakoni playback theatre. Dari definisi tersebut, peserta dengan mudah memahami maksud yang disampaikan. Tidak ada pertanyaan terkait dengan definisi. Begitu pula dengan sejarah jenis teater ini. dalam playback theatre, metode pertunjukannya memanfaatkan teknik bercerita dalam keseluruhan pelaksanaan (Yuliatin, 2020). Metode yang digunakan memiliki perbedaan yang tampak sangat jelas dibandingkan dengan jenis pertunjukan teater konvensional. Pertunjukan playback theatre tidak menggunakan istilah sutradara, akan tetapi peran tersebut digantikan dengan istilah conductor. Kedua istilah ini berbeda, peran sutradara dalam pertunjukan konvesional untuk "mengomandoi" pertunjukkan, sedangkan peran conductor dalam playback theatre untuk memancing cerita itu keluar dari si pencerita (Yuliatin, 2020).

Dalam teater konvensional lakon yang diperankan oleh aktor telah diketahui bahkan dipelajari dengan baik sebelumnya. Sedangkan dalam playback theatre, cerita masih menjadi misteri. Baik aktor, conductor, pemain musik, bahkan yang menyaksikan tidak mengetahui cerita apa yang akan dimainkan. Jika dalam teater konvensional naskah 
didapati dalam bentuk tertulis, dalam playback theatre, cerita datang dari pencerita yang tentu saja berasal dari penonton itu sendiri. Metode playback theatre dapat diurutkan sebagai berikut:

1. conductor meminta salah seorang penonton secara sukarela maju untuk membagi cerita yang dirasa mengganjal di hatinya;

2. penonton yang bersedia mulai bercerita;

3. ketika pencerita membagi kisahnya, conductor tidak menghakimi kisah pencerita, ia bertindak melihat kembali alur, mempertegas peristiwa atau sosok yang dirasa masih kabur;

4. ketika pencerita membagi kisahnya, sembari menyimak aktor menyiapkan scenario (yang tentu saja tidak ditulis) mereka sendiri, begitu pula dengan pemain musik;

5. setelah cerita selesai, conductor mempersilakan para aktor dan pemain musik mulai menyiapkan diri mereka untuk melakukan playback terhadap kisah yang diceritakan pencerita tadi;

6. jika dalam proses playback pencerita mendapati satu momen menyentuh, menyedihkan atau perasaan lain yang mengganggunya, ia dipersilakan mengatakan 'frezz';

7. ketika 'frezz' disebutkan oleh pencerita, aktor dan pemain musik tidak lagi bekerja, mereka mematung untuk membiarkan pencerita meresapi kembali momen atau kejadian tersebut yang dirasa penting.

Playback theatre membutuhkan kemampuan acting dan ketajaman rasa dari aktor, juga kepekaan pemain musik. orang-orang yang terlibat dalam playback theatre memerlukan kemampuan improvisasi yang cakap. Hal ini karena tidak ada scenario dan tidak adanya diskusi cerita dan musik pengiring akan dibuat seperti apa, baik antara aktor satu dengan aktor lain, pemusik satu dengan pemusik lain, atau antara aktor dengan pemusik. Hal lain yang perlu menjadi perhatian adalah kepekaan aktor untuk tidak memainkan peran secara berlebihan. Cerita yang keluar dari pencerita biasanya adalah pengalaman yang tidak menyenangkan, sensitive, atau bersifat sentimental. Aktor harus mampu menguasai diri atau kondisi untuk menjaga kondisi mental pencerita. Jangan sampai playback yang dilakukan sebenarnya untuk mengurangi ketenganan dalam diri pencerita malah membuatnya semakin terpuruk.

Kegiatan berikutnya adalah melakukan olah tubuh. Olah tubuh dilakukan untuk menyiapkan kondisi tubuh peserta. Tubuh dalam teater menjadi alat "kendaraan acting" untuk menampakkan sesuatu cerita yang dimainkan (Marciano, 2017). Olah tubuh dimulai dengan melakukan pemanasan. Teknik olah tubuh yang dililih adalah mirroring. Hal ini bertujuan tidak hanya untuk melatih dan menyiapkan tubuh peserta, tetapi juga untuk membangun kepekaan tubuh dan diri peserta dalam meniru sesuatu. Teknik mirroring https://journal.universitasbumigora.ac.id/index.php/ADMA 
dilakukan dengan membariskan peserta dalam 2 baris berbanjar. Kemudian masing-masing dibuat berhadap-hadapan, memiliki pasangan masing-masing. Dalam pelaksanaannya, teknik mirroring dilakukan dengan seorang menjadi subjek sementara yang lainnya menjadi cermin. Subjek akan membuat gerakan dan ekspresi yang harus direfleksikan oleh yang menjadi cermin. Teknik mirroring yang pada dasarnya memiliki kepentingan peniruan, sehingga dapat membantu menguatakan kepekaan peserta terhadap segala sesuatu yang ada di sekitarnya. Teknik mirroring dapat dapat dilihat prakteknya pada gambar berikut ini.

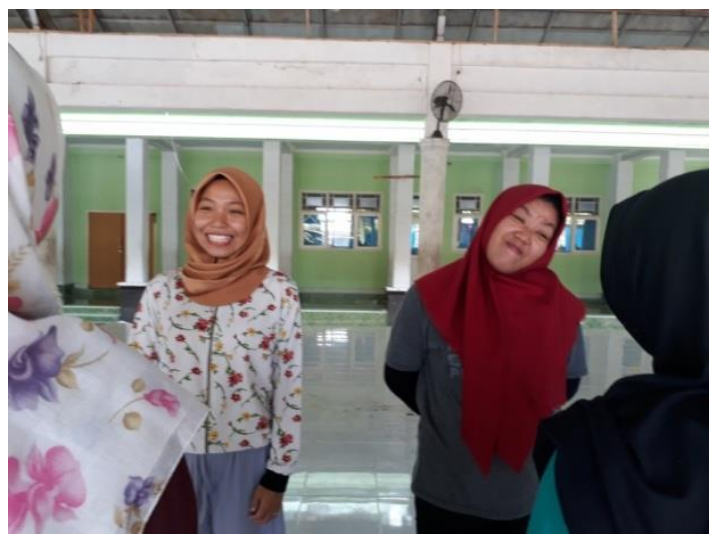

Gambar 2. Peserta melakukan olah tubuh dengan teknik mirroring

Gambar 2 menunjukkan bahwa peserta sedang melakukan peniruan terhadap subjek. Dalam fase ini, mirroring dilakukan dalam tiga tahap. Tahap pertama dimulai dengan peniruan ekspresi wajah hingga batas gerak kepala, tahap kedua mulai melebarkan pada gerak tubuh tapi tanpa adanya moving, dan tahap ketiga pada keseluruhan tubuh (ekspresi wajah dari diri) disertai dengan moving. Teknik mirroring membantu peserta untuk tetap fokus dengan menirukan subjek dan mengabaikan gangguan-gangguan disekitarnya.

Setelah menyelesaikan tahapan olah tubuh, peserta kemudian dibagi dalam tiga bagian kerja. Seorang menjadi conductor, tiga orang menjadi aktor, empat orang menjadi pemain musik, dan sisanya menjadi penonton. Pada pelaksanaannya akan dilakukan pergantian hingga semua peserta mendapat kesempatan dan pengalaman untuk menempati peran-peran tersebut. Dalam melakukan playback theatre, peserta mengikuti metode yang telah disebutkan sebelumnya. Dimulai dengan seorang penonton bercerita, dilanjutkan dengan melakukan playback.

Pada awal pertunjukan, peserta diberikan kesempatan untuk mendiskusikan bentuk musik dan cerita. Setelah pemain mulai terbiasanya, mereka diharuskan meniadakan diskusi dan segalanya dilakukan dengan spontanitas. Seperti telah disebutkan sebelumnya bahwa jenis pertunjukan ini menitikberatkan pada kemampuan improvisasi para pemainnya. 


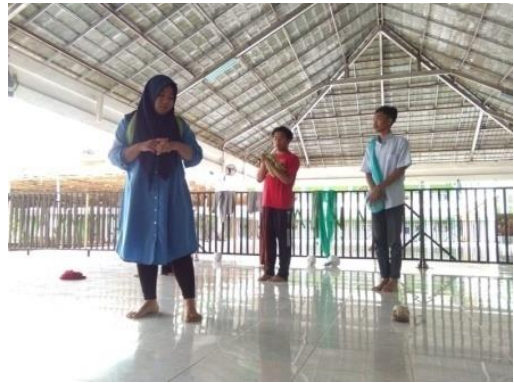

Gambar 3. tiga aktor melakukan playback

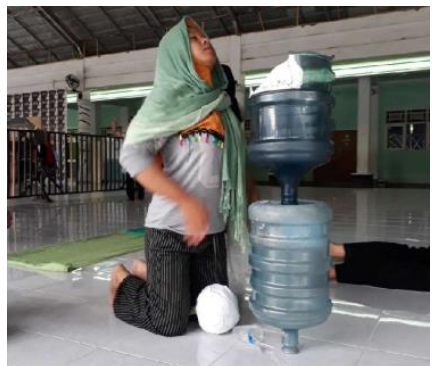

Gambar 5. Aktor melakukan playback dengan properti yang ada

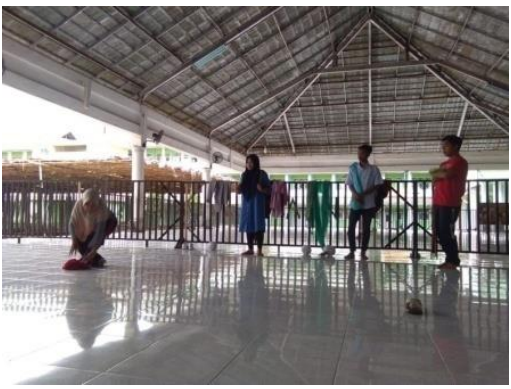

Gambar 4. Ketiga aktor dipersilakan melakukan playback oleh conductor

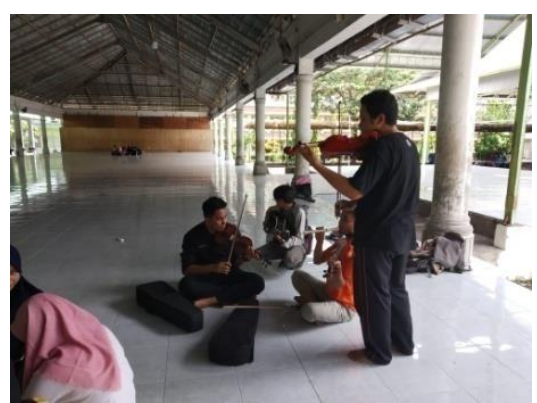

Gambar 6. Pemain musik mencari bentuk musik untuk masing-masing adegan (sumber, (Yuliatin, 2020))

Gambar 3 dan 4 memperlihatkan conductor dan aktor menjalankan peran masingmasing. Gambar tersebut diambil setelah pencerita menyelesaikan ceritanya. Gambar 5 memperlihatkan aktor melakukan playback dengan memanfaatkan properti yang ada. Dalam pertunjukan playback theatre yang tidak dilakukan dengan konsep pertunjukan konvensional. Misalnya, tidak ada panggung atau properti pasti. Dalam playback theatre, properti yang digunakan adalah kain atau selendang. Kain atau selendang bisa sangat fleksible membantu aktor untuk menampilkan menjadi apa dia. Di sini juga dibutuhkan kemampuan aktor untuk merespons cerita dan membentuk propertinya sendiri. Dalam gambar 6 memperlihatkan pemain musik yang sedang merangkai bunyi-bunyian untuk mengiringi pertunjukan. Pemain musik memiliki kriteria tersendiri. Pemain musik harus memiliki pemahaman tentang musik dan jenisnya. Terutama yang berkaitan dengan tone musik yang berkaitan dengan suasana cerita. Untuk memudahkan pemain musik, mereka diminta untuk menyiapkan repertoar bunyi-bunyian yang berkaitan dengan suasana penceritaan. Dalam prakteknya, peserta yang mulanya masih ragu-ragu dalam memainkan peran mulai rileks dan bisa mendalami peran masing-masing. Semakin berlatih, para peserta dapat meningkatkan kepekaan mereka terhadap peristiwa yang diceritakan. Selain itu chemistry antara para aktor dan pemain musik juga dapat dibangun dengan baik sehingga mereka tidak bingung dan canggung lagi dalam melakoni satu cerita. 


\section{Kesimpulan dan Saran}

Playback theatre menjadi salah satu metode berteater yang jarang diketahui oleh mahasiswa. Metode ini biasanya digunakan untuk media pemulihan pasca terjadinya kejadian traumatis dipilihnya mahasiswa sebagai subjek pelatihan dikarenakan mahasiswa nantinya dapat menjadi sumber belajar bagi anak didiknya. Metode playback berbeda dengan berteater pada umumnya sebab tidak membutuhkan skenario dan sangat membutuhkan spontanitas dan improvisasi aktor dan pemain musik. Dengan memperbanyak latihan, para peserta dapat meningkatkan kepekaan mereka terhadap cerita. Selain itu chemistry antara para aktor dan pemain musik juga dapat terbangun dengan baik. mereka tidak bingung dan canggung lagi dalam melakoni satu cerita.

\section{Daftar Pustaka}

Fox, H. (2007). Playback Theatre: Inciting Dialogue and Building Community through Personal Story. TDR/The Drama Review, 51(4), 89-105. https://doi.org/https://doi.org/10.1162/dram.2007.51.4.89

Hadriami, E., \& Samuel, S. (2016). Terapi Pemanfaatan melalui Playback Theater untuk Mengurangi Rasa Sakit Hati. Psikodinamika, 15(1), 1-23. http://journal.unika.ac.id/index.php/psi/article/view/589

Hasiana, I. (2019). METODE BERCERITA SEBAGAI UPAYA PEMULIHAN TRAUMA PASCA BENCANA PADA ANAK USIA DINI Oleh: 73| Metode Bercerita Sebagai Upaya Pemulihan Trauma Pasca Bencana Pada Anak Usia Dini. 03.

Hatta, K. (2016). Trauma Dan Pemulihannya Suatu Kajian Berdasarkan Kasus Pasca Konflik dan Tsunami.

Marciano, R. (2017). Olah Tubuh Teater. TEROB, 8(1), 1-15. https://doi.org/https://doi.org/10.20111/st.v8i1.88

Moran, G. S., \& Alon, U. (2011). Playback Theatre and Recovery in Mental Health: Preliminary

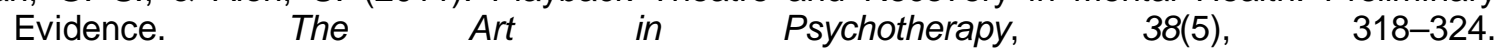
https://doi.org/https://doi.org/10.1016/j.aip.2011.09.002

Rogers, T. (2005). Community Dialogue \& Healing Through Playback Theatre. University of the West Indies.

Wastap, J. (2019). Teater Sebagai Media Komunikasi Pendidikan. Jurnal ASPIKOM, 3(6), 1124. https://doi.org/10.24329/aspikom.v3i6.414

Yuliatin, R. R. (2020). Playback Theatre sebagai Metode Pelepasan Ketegangan Pasca Gempa Lombok pada Anak-Anak. ABDI POPULIKA, 1(1), 1-11.

Yuliatin, R. R., \& Satrya, D. (2019). Logat, Volume 6, No 2, November 2019. LOGAT: Jurnal Bahasa Indonesia Dan Pembelajaran, 6(2), 137-150. 